\title{
Assessment of Near-Infrared (780nm) Light Transillumination Accuracy for Detection of Incipient Caries Lesions
}

\begin{abstract}
CLAUDIU TOPOLICEANU, CRISTINA-ANGELA GHIORGHE*, VASILICA TOMA*, SORIN ANDRIAN, GIANINA IOVAN, SIMONA STOLERIU, GALINA PANCU, IRINA NICA, MIHAELA SALCEANU

Grigore T. Popa University of Medicine and Pharmacy, Faculty of Dental Medicine, 16 Universitatii Str., 700115, Iasi, Romania

The aim of study was to evaluate the accuracy of the near-infrared light transillumination technique used in the detection of the proximal incipient dental caries. The study was performed on 12 medium caries risk subjects (mean age of 26.5). A total number of 312 proximal dental surfaces from the posterior dental group were included in the study. All the proximal surfaces, which had not been restored, or unaffected by cavitated dental caries, were assessed by a near-infrared transillumination camera system using light with a 780nm wavelength (DIAGNOcam, KaVO). Bitewing radiographies were performed for all patients included in study. Visual and tactile examination after tooth separation was performed as gold standard to detect the incipient proximal dental caries (ICDAS scores 02 and 03). Statistical analysis using Chi-square test was performed to compare the diagnostic performance of near-infrared light transillumination and the bitewing radiography. Near-infrared light transillumination showed higher sensitivity (81.80\%) when compared to bitewing radiography (65.90\%) to detect the non-cavitated proximal enamel caries (ICDAS score 02). Nearinfrared light transillumination method showed higher sensitivity (100\%) when compared to bitewing radiography (81.50\%) to detect the incipient cavitated proximal enamel caries (ICDAS score 03). Specificity values for proximal incipient dental caries (ICDAS codes 02 and 03) were 95.03\% for near-infrared light transillumination and $99.18 \%$ for bitewing radiography. DIAGNOcam (KaVO) is a reliable tool with high diagnostic accuracy of the incipient dental caries localized on proximal surfaces of the posterior dental group.
\end{abstract}

Keywords: proximal caries lesion, detection, near-infrared light transillumination, DIAGNOcam

Traditionally, dental practitioners were focused on the detection of the dental caries in the cavitation stage as well as on the invasive, operative treatment. The restorative approach has remained for many decades the main therapeutic strategy for dental caries control, but it was associated to high rate of failures, due to the flaws of adhesive systems and composite materials. A new conceptbased on the remineralization of the non-cavitated enamel caries was introduced in the dental practice [1]. The preventive measures reduced drastically the epidemiology of occlusal dental caries, but early proximal caries seems to represent a challenge for modern dentistry. The researches proved the remineralization of white-spot carious lesions on smooth enamel surfaces with direct access to saliva with normal $\mathrm{pH}$ and high calcium and phosphate ions concentration [2,3]. The early detection of the proximal enamel demineralization offers the possibility for non-invasive or minimal invasive interventions based on fluoridation [4], applications of remineralization products [5], or infiltration (ICON method) [6].

In the diagnostic of the incipient proximal caries clinical examination alone has low values of sensitivity (correctly identified demineralized enamel and dentine surfaces) and specificity (correctly identified sound enamel and dentine surfaces) [7]. The introduction of new clinical scores system for caries lesions detection (ICDAS), based upon the histological extent of demineralization, allows better quality information, as well as appropriate diagnosis, prognosis and clinical management of dental caries [8]. However, when proximal demineralization enamel areas must be detected, this system can be used effectively only after the tooth separation. Widely used for the detection of proximal caries lesions, byte-wing radiography (BW) has high specificity, but the sensitivity is highly dependent on the extent of caries damage to the dentine [9]. Nearinfrared light transillumination (NILT) is one of the novel dental technologies that have emerged in the dental practice. This technology is based on a specific light of 780 $\mathrm{nm}$ wavelength emitted by a laser diode that can penetrate dental crowns, gingiva, alveolar process and dental roots. The demineralization areas stop the penetration of light and are displayed as dark shadows. The advantages are as follows: system motivating for patients due to images of demineralization areas displayed immediately at highresolution screening, it facilitates the communication dentist-patient, can be repeated to compare the previous results with new results [10]. The use of this technology is encouraged by the recommendation of International Commission on Radiological Protection for the decrease of dose radiation in all fields of medicine, including dental medicine [11].

The aim of study was to evaluate the accuracy of nearinfrared light transillumination technique used in early proximal caries lesions detection.

\section{Experimental part}

Materials and methods

The study was conducted on 12 subjects ( 6 females, 6 males) with age between 18 and 34 (mean age 26.5). The patients were selected from M. Kogalniceanu Dental Clinic, Faculty of Dental Medicine, Grigore T.Popa University of Medicine and Pharmacy lasi. The sample consisted of 140 molars proximal surfaces and 172 premolars proximal surfaces. The inclusion criteria for the study were as follows: (1) patients' age between 18-35; (2) medium cariogenic risk; (3) untreated proximal surfaces of molars

*email: drangycris@yahoo.com; vasilicatoma40@yahoo.com 
and premolars; (4) proximal surfaces of molars and premolars unaffected by cavitated dental caries. The exclusion criteria for the study were as follows: (1) teeth with proximal cavitated carious lesions; (2) teeth with shadow of discolored dentin visible through an apparently intactmarginal ridge. Subjects were required to be available during the study, and to sign an informed consent. It was provided an informed consent about the aims to all participants. The data file remained anonymous, and the identity of the participants was protected. The study was done in accordance with the Ethical Committee regulations and in accordance to some published models [12]. The assessment of the dental proximal surfaces (according to inclusion criteria), by using visual and tactile examination and intraoral camera examination after teeth separation with interdental elastic wedges (TDV, Brasil), was performed as gold standard. ICDAS system was used for the detection of the incipient proximal caries. The definitions of ICDAS scores 02 and 03 for the proximal surfaces are as follows: score 02- distinct visual change in enamel visible when wet; score 03- initial breakdown in enamel due to caries without clinical visual signs of dentinal involvement [13].

All patients underwent bitewing radiography and the assessment of proximal dental surfaces by near-infrared transillumination camera system using light with a wavelength of $780 \mathrm{~nm}$. The bitewing radiographs were taken using exposure parameters set at $70 \mathrm{kV}, 7 \mathrm{~mA}$, with 0.16-0.20 s exposure time. For near-infrared light transillumination technique, DIAGNOcam 2170U (Kavo, Biberach, Germany) was used with the KaVo integrated desktop (KID) software V 2.4.2 and replaceable tips for adults. Images were obtained and recorded, using the camera at different angles from the proximal areas of molars and premolars. The best angle image was saved in the patient's virtual chart. The image obtained from the camera was evaluated according to the Hinze classification [14]: 0 - light transmission unchanged; 1 - shadow visible in the enamel; 2 - shadow visible in the dentin. The observer was a specialist dealing with caries detection as a daily routine activity.

The sensitivity and specificity of the near-infrared light transillumination technique and bitewing radiography were calculated for proximal incipient caries having ICDAS scores of 02 and 03 . To calculate sensitivity and specificity it was used the next formula: Sensitivity = True positives/ (True positive + False negative); Specificity $=$ True negatives/(True negative + False positives). Statistical tests were performed to compare near-infrared light transillumination sensitivity and specificity to byte-wing radiography in early proximal caries detection. The statistical data analysis was performed in SPSS 20.0 (SPSS, Chicago, IL, USA). Excel sheet were used to generate tables.
Chi-squared tests were used to investigate the difference between the accuracy of the two investigation methods. The level of statistical significance was set at 0.05 .

\section{Results and discussions}

Following visual and tactile examination and intraoral camera examination after teeth separation (gold standard), 241 proximal surfaces $(77.2 \%)$ were found as healthy and 71 proximal surfaces $(22.8 \%)$ were identified with early caries as follows: ICDAS 02 (44 proximal surfaces -14.1\%); ICDAS 03 (27 proximal surfaces $-8.7 \%$ ). In the group of proximal dental surfaces scored with 02 in ICDAS system bitewing radiography detected 29 proximal surfaces with early demineralization (sensitivity $65.9 \%$ ). In the group of the proximal dental surfaces scored with 02 in ICDAS system, near-infrared light transillumination detected 36 proximal surfaces with early demineralization (sensitivity $81.8 \%$ ). In the group of the proximal dental surfaces scored with 03 in ICDAS system bitewing radiography detected 22 proximal surfaces with early demineralization (sensitivity $81.5 \%$ ). In the group of the proximal dental surfaces scored with 03 in ICDAS system near-infrared light transillumination detected 27 proximal surfaces with early demineralization (sensitivity $100 \%$ ). The research also investigated the specificity of bitewing radiography and near-infrared light transillumination. Bitewing radiography detected two proximal dental surfaces with early demineralization (false positive) and near-infrared light transillumination detected 12 proximal surfaces with early demineralization (false positive) that were not confirmed with incipient carious lesions in the gold standard examination. Reporting these results to the total number of healthy proximal dental surfaces (241), the specificity values were $95.03 \%$ for near-infrared light transillumination and $99.18 \%$ for bitewing radiography.

The results of statistical analysis are presented in table 1. Near-infrared light transillumination detected more proximal surfaces scored as 02 in ICDAS system when comparing to bitewing radiography, but the differences were not statistically significant $(p=0.549, p>0.05$ ). Near-infrared light transillumination detected more proximal surfaces with early dental caries (scored with 02 and 03 in ICDAS system) when comparing to bitewing radiography, but the differences were not statistically significant $(p=0.832, p>0.05)$. No significantly statistical differences were found between sensitivity of bitewing radiography in the detection of the proximal dental surfaces scored as 03 versus those scored as 02 in ICDAS system $(p=0.157, p>0.05)$. Significant statistical differences were found for near-infrared light transillumination to detect proximal dental surfaces scored as 03 in ICDAS system versus those scored as $02(p=0.019)$. Specificity of nearinfrared light transillumination was lower when compared

Table 1

CHI-SQUARED TEST FOR COMPARISONS BETWEEN NEAR-INFRARED LIGHT TRANSILLUMINATION AND BITEWING RADIOGRAPHY (SENSITIVITY, SPECIFICITY)

\begin{tabular}{|c|c|c|c|c|}
\hline Sensitivity & Sensitivity & Sensitivity & Sensitivity & Specificity \\
\hline $\begin{array}{c}\text { ICDAS 02 } \\
\text { (NILT vs. BW) }\end{array}$ & $\begin{array}{l}\text { ICDAS } 02+03 \\
\text { (NILT vs. BW) }\end{array}$ & $\begin{array}{c}\mathrm{NILT} \\
\text { (ICDAS 02 vs. 03) }\end{array}$ & $\begin{array}{c}\text { BW } \\
\text { (ICDAS } 02 \text { vs. 03) }\end{array}$ & NILT vs. BW \\
\hline$p=0.549$ & $p=0.832$ & $p=0.019$ & $\mathrm{p}=0.157$ & $p=0.745$ \\
\hline
\end{tabular}
${ }^{8} p<0.05$

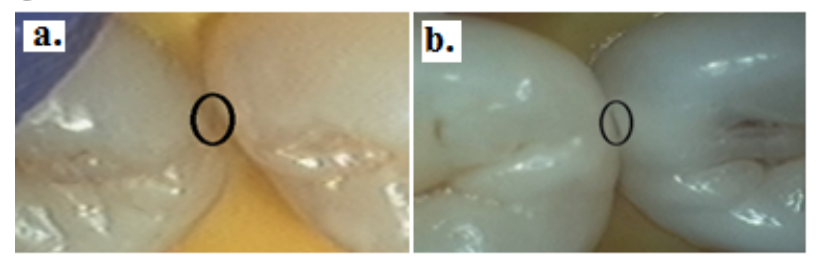

Fig.1. Incipient proximal dental caries detected after teeth separation: a-ICDAS score 02 (1.6-mesial surface); b- ICDAS score 03(2.6-mesial surface) 


\begin{tabular}{|c|c|c|}
\hline Significance & $\begin{array}{l}\text { Bitewing radiographic } \\
\text { image }\end{array}$ & $\begin{array}{c}\text { DIAGNOcam (KaVO } \\
\text { Image }\end{array}$ \\
\hline $\begin{array}{l}\text { Absent demineralization } \\
\text { 4.6. (mesial surface) }\end{array}$ & & \\
\hline $\begin{array}{l}\text { Enamel demineralization } \\
2.5 \text {. (distal surface) }\end{array}$ & & \\
\hline $\begin{array}{l}\text { Demineralization limited to } \\
\text { enamel-dentin junction } \\
3.5 \text {. (distal surface) }\end{array}$ & & \\
\hline $\begin{array}{l}\text { Demineralization extended to } \\
\text { dentin external third } \\
\text { 2.4. (distal surface) }\end{array}$ & & \\
\hline
\end{tabular}

Table 2

NEAR-INFRARED LIGHT TRANSILLUMINATION AND RADIOGRAPHIC ASPECTS with bitewing radiography, but the ditterences were not statistically significant ( $p=0.745, p>0.05$ ).

Figures $1 a$ and $b$ show incipient proximal caries detected in intraoral camera examination after teeth separation. Near-infrared light transillumination and bitewing radiographic aspects of the investigated dental proximal surfaces are presented in table 2.

A special care must be addressed to proximal surfaces when are detected factors that increase the caries risk [15-17]. These demineralization areas progress slowly, allowing secondary preventive strategies to be implemented when the lesions have the greatest opportunity to arrest [18-20].

The present randomized clinical and paraclinical study investigated the sensitivity and specificity of near-infrared transillumination technique regarding the detection of early proximal caries on a group of medium caries risk patients. The sensitivity and specificity are used to describe and quantify the diagnostic accuracy of a test [21]. The visual and tactile examination associated with examination with intraoral camera after tooth separation was referred as gold standard. We used a group of patients with medium cariogenic risk, and not a sample with high caries prevalence, higher than in real clinical situations, to avoid an overestimation of test sensitivity at disease level. Also, by including the medium caries risk patients, and not a sample with low caries prevalence, we avoided the inclusion of too many sound surfaces that w ould cause an overestimation of specificity [21]. During the study, we focused on the avoidance of the false positive diagnostic as researchers consider now that the detection of the caries lesions should be focused on the elimination of sound surfaces, instead on the detection of false positive diagnostic that would lead to overtreatment and unnecessary invasive treatments [22].

Only a few studies have been conducted with clinical validation and aimed to determine the diagnostic performance of near-infrared light transillumination in the detection of early proximal caries lesions. In our study we found an underestimation of caries lesions with ICDAS score of 02 in byte-wing radiography, as only $65.90 \%$ was detected using this additional method. This result is in correlation with a research that found the detection of enamel caries by Rx only for the dental surfaces with at least 30\% demineralization [23]. Also, overlapping layers (the carious lesion covered by orthodontic appliances or by hard dental tissue of the adjacent dental crown) may lead to the lower sensitivity and underestimation of the depth of the carious lesion [24]. Regarding near-infrared light transillumination, a higher percent of early proximal demineralization areas was detected (81.80\%), proving the superiority of this diagnostic method over byte-wing radiography. Near-infrared light transillumination detected all proximal surfaces with ICDAS score of 03 (associated with incipient cavitation in enamel), while only $81.50 \%$ were detected by using bitewing radiography. The results of our study are in accordance with recent researches that compared near-infrared light transillumination with bitewing radiographs [35-40]. Ozkan et al. [25] found similar sensitivity (0.82-0.83) for near-infrared light transillumination and bitewing radiography, significantly higher than visual and tactile examination (0.51) in the detection of early proximal dental caries. Similar results regarding sensitivity and specificity of near-infrared light transillumination and bitewing radiography were found in vivo by Baltacioglu etal. [26]. In an in vitro study Abogazalah et al. [27] found, higher values for sensitivity and specificity when near-infrared light transillumination $(0.68 / 0.93)$ was compared with digital radiography (0.50/0.64). In a clinical study, Kûhnisch etal. [28] open and validated as reference standard proximal caries with diagnostic accuracy $99.2 \%$ for near-infrared transillumination and $96.1 \%$ for digital radiography, values significantly higher than laserfluorescence $(66.7 \%)$ or visual inspection. Sõchtig et al. [29] found in vivo that near-infrared light transillumination have similar diagnostic performances as that of bitewing radiographs in the examination of proximal surfaces. In vitro researches performed by Maia et al. [30] found better sensitivity and specificity for the detection of early approximal caries by near-infrared light transillumination $(0.88 ; 0.72)$ comparing to bitewing radiography $(0.53$; $0.72)$.

The clinical validation is reported as usual limitation of similar in vivo studies, due to ethical rules, because of potential overtreatment. Our study overpassed this 
limitation by using ICDAS system in the assessment of the proximal surfaces. The evaluation of the proximal surfaces by only one observer made impossible to calculate reproducibility. Further studies should be conducted with inclusion of two observers for diagnosing the early proximal caries. Also, a study performed on teeth planned for orthodontic extractions could allow clinical validation and the assessment of the diagnostic accuracy in relation to the histological depth of the proximal demineralization.

\section{Conclusions}

This study demonstrated that DIAGNOcam (KaVO) is a reliable tool with high diagnostic accuracy of the incipient dental caries localized on proximal surfaces of the posterior dental group. The sensitivity of DIAGNOcam (KaVO) is higher when compared with bitewing radiography, but not statistically significant. Bitewing radiography has higher specificity than near-infrared light transillumination, without significant statistical differences.

Acknowledgments. Special acknowledgment to HTP Medical that provided near-infrared light transillumination device DIAGNOcam (KaVO, Germany) during the study period.

\section{References}

1.IOVAN, G., STOLERIU, S., GHIORGHE, C.-A., CIMPOESU, N., GEORGESCU, A., ANDRIAN S., Mat.Plast., 51, no. 4, 2014, p.421. 2.IOVAN, G., GHIORGHE, C.-A, STOLERIU, S., PANCU, G., NICA, I., TARABOANTA, I., ANDRIAN, S., Mat.Plast., 55, no. 2, 2018, p.233.

3.IOVAN, G., GHIORGHE, C.-A, STOLERIU, S., PANCU, G., ANDRIAN, S., Mat.Plast., 51, no. 3, 2014, p.282.

4.IOVAN, G., STOLERIU, S., NICA, I., SOLOMON, S., MUNTEANU, A., ANDRIAN, S., Mat.Plast., 53, no. 4, 2016, p.755.

5.IOVAN, G., STOLERIU, S., PANCU, G., NICA, I., ANDREI, V.S., ANDRIAN, S., Mat.Plast., 54, no. 2, 2017, p.375.

6.BOLAT, M., STOLERIU, S., IOVAN, G., PANCU, G., TOFAN, N., SANDU, A.V., ANDRIAN, S., Mat.Plast., 55, no. 3, 2018, p.434

7.STOLERIU, S., ANDRIAN S., NICA, I., Mat.Plast., 54, no. 3, 2017, p.574.

8.TARABOANTA, I., STOLERIU, S., IOVAN, G., MOLDOVANU A., GEORGESCU A., NEGRAIA M.R., GHIORGHE, C.-A, ANDRIAN, S., Mat.Plast., 55, no. 2, 2018, p.238.

9.STOLERIU, S., IOVAN, G., NICA, I., PANCU, G., SANDU, A.V., ANDRIAN, S., Mat.Plast., 55, no. 4, 2018, p.584.

10. ANDRIAN, S., Tratamentul minim invaziv al cariei dentare, Ed. Princeps, Iasi, 2002.

11.STOLERIU, S., GHIORGHE, C.-A., POPA, C., STELEA, C., STEFANESCU, O., IOVAN, G., Romanian J ournal of Oral Rehabilitation, 9, no. 2, 2017, p. 37.

12.GHIORGHE, C.-A., SALCEANU, M., TOPOLICEANU, C., LUCA, E., ANCUA, C., IORDACHE, C., Romanian J ournal of Oral Rehabilitation, 9, no. 4, 2017, p. 30.

13.GHIORGHE, C.-A., ANDRIAN, S., PANCU, G., NICA, I., IOVAN, G., Romanian Journal of Oral Rehabilitation, 8, no. 4, 2016, p. 67.

14. BAELUM, V., HEIDMANN, J., NYVAD, B., Eur J Oral Sci, 114, no. 4, 2006, p. 263.
15. STOLERIU, S., IOVAN, G., PANCU, G., GEORGESCU, A., SANDU, A.V., ANDRIAN, S., Rev. Chim. (Bucharest), 63, no.11, 2012, p. 1120.

16. TOPOLICEANU, C., STOLERIU, S., GHIORGHE, C.-A., SALCEANU, M., SANDU, A.V., ANDRIAN, S., Rev. Chim. (Bucharest), 64, no. 11, 2013, p. 1324.

17. PANCU, G., ANDRIAN, S., TOPOLICEANU, C., TOFAN, N., NICA, I., GHIORGHE, C.-A., STOLERIU, S., IOVAN, G., Rev. Chim. (Bucharest), 68, no. 7, 2017, p.1607.

18. PANCU, G., IOVAN, G., GHIORGHE, C.-A., TOPOLICEANU, C., NICA, I., TOFAN, N., STOLERIU, S., SANDU, A.-V., ANDRIAN, S., Rev. Chim. (Bucharest), 66, no.12, 2015, p. 2051.

19. PANCU, G., ANDRIAN, S., IOVAN, G., NICA, I., GHIORGHE, C.-A., SANDU, A.-V., STOLERIU, S., Rev. Chim. (Bucharest), 67, no. 11, 2016, p. 2351.

20. STOLERIU, S., IOVAN, G., GHIORGHE, C.-A., NICA, I., PANCU, G., GEORGESCU, A., ANDRIAN, S., Rev. Chim. (Bucharest), 66, no. 11, 2015, p. 1772.

21. PANCU, G., ILIE, M., ANDRIAN, S., IOVAN, G., TOPOLICEANU, C., PANCU, I., GHEORGHE, A., MOLDOVANU, A., STOLERIU, S., Romanian Journal of Oral Rehabilitation, 4, no.3, 2012, p. 43.

22. PANCU, G., ANDRIAN, S., IOVAN, G., GHIORGHE, A., TOPOLICEANU, C., MOldOVANU, A., GEORGESCU, A., PANCU, I., STOLERIU, S., Romanian J ournal of Oral Rehabilitation, 3, no. 1, 2011, p. 94.

23. HOSKIN, E.R., KEENAN, A.V., Evid Based Dent., 17, no.2, 2016, p. 41.

24. DIKMEN, B., J Istanb Univ Fac Dent., 49, no.3, 2015, p. 63.

25. MEJ ARE, I., AXELSSON, S., DAHLEN, G., ESPELID, I., NORLUND, A., TRANCUS, S., TWETMAN, S., Acta Odontol. Scand., 72, no.2, 2008, p. 81.

26. ABDELAZIZ, M., KREJ Cl, I., PERnEGeR, T., FEILZER, A., Int. J. Esthet. Dent, 10, no.1, 2015, p. 158.

27. LUDLOW, L.B., DAVIES-LUDLOW, L.E., WHITE, S.C., J. Am. Dent. Assoc., 139, no.9, 2008, p. 1237.

28.AGHEORGHIESEI CORODEANU, D.T., POROCH, V., 6th LUMEN International Conference on Rethinking Social Action Core Values, 16-19 April 2015, Iasi, Romania, Rethinking Social Action. Core Values, p.33.

29. GUGNANI, N., PANDIT, I.K., SRIVASTAVA N, GUPTA, M., SHARMA, M., Int. J. Clin. Pediatr. Dent., 4, no.2, 2011, p 93.

30. HINZE, H., WENZEL A. Dentomaxillofac. Radiol., 25, 1996, p. 116. 31. ALTMAN, D.G., BLAND, J.M., BMJ, 308, no.6943, 1994, p. 1552.

32. BAELUM, V., HINTZE, H., WENZEL, A., DANIELSEN, B., NYVAD, B., Community Dent. Oral Epidemiol, 40, no.3, 2012, p. 257.

33. WENZEL, A., Acta Odontol. Scand., 72, no.4, 2014, p. 251.

34. WENZEL, L., J ournal of Dental Research, 83, no. 1-suppl., 2004, p. 72.

35. OZKAN, G., GUZEL, K.G.U., Lasers Med Sci., 32, no.6, 2017, p. 1417.

36. BALTACIOGLU, I.H., ORHAN, K., BMC Oral Health., 17, no.1, 2017, p. 130.

37. ABOGAZALAH, N., ECKERT, G.J ., ANDO, M., J Dent, 63, 2017, p. 44. 38. KUHNISCH, J., SOCHTIG, F., PITCHIKA, V., LAUBENDER, R., NEUHAUS, K.W., LUSSI, A., HICKEL, R., Clin Oral Investig, 20, no.4, 2016. p. 821.

39.SOCHTIG, F., HICKEL, R., KUHNISCH, J., Quintessence International, 2014, p. 531.

40. MAIA, A.M., KARLSSON, L., MARGULIS, W., GOMES, A.S., Dentomaxillofac Radiol, 40, no.7, 2011, p. 429.

Manuscript received: 11.10 .2018 